\title{
Regional and local emissions in red river delta, Northern Vietnam
}

\author{
V. T. Bac $\cdot$ P. D. Hien
}

Received: 22 March 2009 / Accepted: 4 May 2009 / Published online: 26 May 2009

(C) The Author(s) 2009. This article is published with open access at Springerlink.com

\begin{abstract}
Fine $\left(\mathrm{PM}_{2.2}\right)$ and coarse $\left(\mathrm{PM}_{2.2-10}\right)$ particles concurrently collected in urban (Hanoi) and rural (Lucnam) areas were analyzed for ionic and elemental compositions to provide input for PMF receptor modeling of emission sources in the Red River Delta (RRD), a key economic development region in Vietnam. Long-range transport (LRT) aerosol, coal fly ash from major coal-fired plants in $\mathrm{RRD}$, and marine aerosols are regional sources, which explain the minor variability of the mass concentrations of fine particles across the region. Local sources include soil/ resuspended road dust, local coal fly ash, and biomass burning. Soil/resuspended road dust is the largest source component of coarse particles at the two sites. It is more abundant in Hanoi than in Lucnam reflecting the urbanrural contrast in traffic and construction works. Receptor models reveal the incorporation of secondary sulfate, nitrate, and ammonium into the various primary particles, i.e., soot, minerals, soil organic matter, and sea salt. Soot particles from LRT carry the largest amounts of sulfate and ammonium mass concentrations measured at the two sites. Based on receptor models, the yields and possible chemical forms of secondary sulfate, nitrate, and ammonium in different types of primary particles can be inferred.
\end{abstract}

Keywords PIXE · Ion chromatography .

Positive matrix factorization .

Primary and secondary constituents

V. T. Bac $\cdot$ P. D. Hien $(\bowtie)$

Vietnam Atomic Energy Commission,

59 Ly Thuong Kiet,

Hanoi, Vietnam

e-mail: pdhien@gmail.com

\section{Introduction}

With 20 million people inhabiting an area of $16,640 \mathrm{~km}^{2}$, the Red River Delta (RRD) in northern Vietnam, which includes the capital Hanoi, the port city Haiphong and the coastal area of the World Heritage Halong Bay (Fig. 1), is among the most densely populated regions in the world (Government of Vietnam/UNPD/World Bank 1995). Over the last 15 years, energy consumption in this key economic development zone of Vietnam has dramatically increased to meet the demands of its boom economy. Most of the country's major coal-fired plants for electricity generation and cement production are located in the RRD taking advantage of the proximity to the coal mines in northeastern Vietnam. Petrol consumption increased twofold from 2001 to 2006. More than $90 \%$ of the four million registered vehicles in the RRD are motorcycles, which are regarded as the most harmful mobile source of air pollutants in many Asian cities (Leong et al. 2001; Clean Air Initiative for Asian Cities 2007).

The burning of low-quality fuels coupled with lax emission controls has caused a rapid deterioration in air quality in both urban and rural areas of the RRD. In Hanoi (urban), the $\mathrm{PM}_{10}$ and $\mathrm{PM}_{2.5}$ concentrations considerably exceed the permissible levels with multiday pollution episodes occurring frequently in winter (Hien et al. 2002). Pollutant gases from fuel burning, such as $\mathrm{SO}_{2}$ and $\mathrm{CO}$, exceed the levels present in Hong Kong (National HydroMeteorological Service of Vietnam 2004; The Government of the Hong Kong Special Administrative Region 2006). Receptor modeling for a background site in Hanoi shows the dominance of resuspended road dust containing secondary sulfate, nitrate, and ammonium in coarse particles and long-range transport (LRT) soot particles containing ammonium sulfate in fine particles. Other 
Fig. 1 Map of northern Vietnam

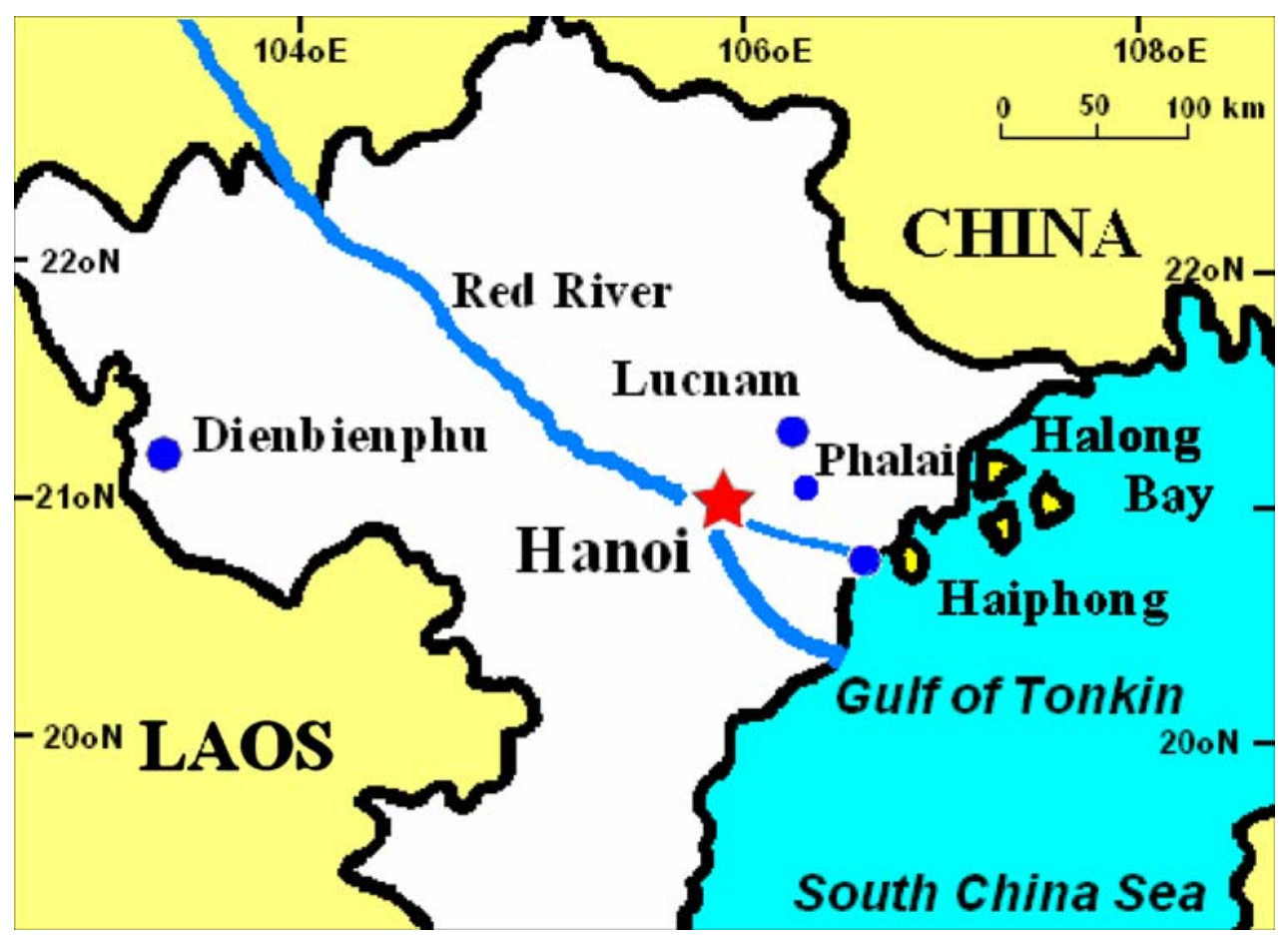

emission sources include coal and biomass burning, vehicle exhaust, and marine aerosols (Hien et al. 2004).

Concerning rural areas, a screening campaign conducted prior to this work at 12 rural sites across the RRD found a substantial reduction of coarse particles $\left(\mathrm{PM}_{2.2-10}\right)$, but a rather similar level of fine particles $\left(\mathrm{PM}_{2.2}\right)$ as compared to Hanoi (Hien 2003). The mean ( \pm standard deviation) ruralto-urban concentration ratio is $0.56( \pm 0.20)$ and 0.90 $( \pm 0.21)$ for $\mathrm{PM}_{2.2-10}$ and $\mathrm{PM}_{2.2}$, respectively. The reduction of $\mathrm{PM}_{2.2-10}$ in rural settings obviously reflects the urbanrural contrast in traffic and construction/road works, while the limited variability of $\mathrm{PM}_{2.2}$ across the RRD suggests the dominant contribution from regional and LRT aerosols.

In order to reduce the level of airborne particles in the $R R D$, it is therefore imperative to understand the impacts of regional vs. local sources and of the processes leading to the formation of secondary aerosols from pollutant gases. An urban-rural comparative receptor modeling of $\mathrm{PM}_{2.2}$ and $\mathrm{PM}_{2.2-10}$ could provide insights into these issues.

For this purpose, 24-h air particulate samples were concurrently collected in Hanoi and at a village Lucnam, about $60 \mathrm{~km}$ to the east-northeast of the city. Samples were analyzed for ionic and elemental compositions using ion chromatography (IC) and proton induced X-ray emission (PIXE) methods. Some preliminary features of urban and rural sources were recognized by comparing chemical compositions of particles at the two sites. However, more comprehensive source patterns were obtained by receptor modeling in the form of positive matrix factorization (PMF).
The PMF model consists of factor composition profiles (F-factors) and factor scores (G-factors). The comparison of F-factors for the urban and rural sites reduced the ambiguity of source identification. On the other hand, the regional or local character of a source could be validated by using the correlation between urban and rural factor scores. Thus, LRT aerosols at the urban and rural sites are expected to have similar factor composition profiles, comparable mass loadings, and a high correlation of factor scores. Furthermore, based on factor composition profiles, the yields and possible chemical forms of secondary sulfate, nitrate, and ammonium in different types of airborne particles could be inferred.

\section{Description of sites}

Located in the coastal region of northern Vietnam, the RRD has a classical triangular form with its apex some $150 \mathrm{~km}$ inland and its base extending $130 \mathrm{~km}$ along the coastline of the Gulf of Tonkin (Fig. 1). The Hanoi metropolitan area $\left(21.02^{\circ} \mathrm{N}, 105.85^{\circ} \mathrm{E}\right)$ with over 2 million inhabitants is located about $100 \mathrm{~km}$ west of the coastline and $150 \mathrm{~km}$ from the borders with China and Laos. The rural site in Lucnam $\left(21.18^{\circ} \mathrm{N}, 106.33^{\circ} \mathrm{E}\right)$ is not far from the ranges lying along the northeast flank of the RRD, about $65 \mathrm{~km}$ to the east-northeast of Hanoi.

In Hanoi, particulate samples were collected at the Meteorological Garden, which can be regarded as a city background site, about $100 \mathrm{~m}$ from a roadway and $8 \mathrm{~km}$ from the southern industrial suburban area. In Lucnam, air 
samples were collected on the roof of a two-story house in a village surrounded by a paddy field. Several major coalfired plants for production of electricity, cement, and chemicals in the RRD are expected to affect both sites.

Meteorological conditions in Hanoi and Lucnam are controlled by the East Asia monsoon regime, which is driven by the cold air from the Asiatic High in winter and the humid hot air from the Highs over the Indian and Pacific Oceans in summer (Toan and Dac 1993; Hien et al. 2004). The cyclic movement of these air masses results in a strong seasonal variation in rainfall with a maximum in July-August and a minimum in December-January. Meteorological parameters are routinely measured only at the Hanoi site.

\section{Sampling and sample analysis}

A Gent Stacked Filter Unit was used to collect separately coarse and fine particles on 47-mm-diameter nuclepore polycarbonate filters. Seventy pairs of samples were collected at each site from January 2001 through July 2002. The air sampler provides a cut-off for the fine fraction at $2.2 \mu \mathrm{m}$ (Hopke et al. 1997). Nuclepore filters were pre- and post-weighed to determine the gravimetric mass of the collected materials using a Mettler balance of $1 \mu \mathrm{g}$ readability placed in a dedicated room with controlled temperature and humidity. The filters were acclimatized to room conditions for 3-4 days prior to weighing. A ${ }^{210} \mathrm{Po}$ electrostatic charge eliminator was used to neutralize charges accumulated on the filters before weighing. A colocated sampling experiment showed that the two air samplers produce similar particulate mass concentrations within $\pm 7 \%$.

Loaded filters were kept in a refrigerator until analysis to minimize volatilization. They were then analyzed for water-soluble ions, elemental components, and black carbon (BC) using IC, PIXE, and optical reflectance methods, respectively. $\mathrm{BC}$ can be regarded as an indicator of soot particles; it was not measured for coarse $\mathrm{PM}_{10}$ samples because light absorption may be attributed to materials such as coarse soil humus particles. In addition, fine nitrate values were not used in data analysis to avoid nitrate-sampling artifacts. Details of the IC and reflectance methods have been described in Hien et al. (2004). The PIXE method using the facility of the National University of Singapore has been described in Lal and Tang (1993). The relative uncertainty of the concentrations was about $2 \%$ for particulate masses, $5-10 \%$ for abundant species $\left(\mathrm{SO}_{4}{ }^{2-}\right.$ and major crustal elements in the coarse fraction and $\mathrm{SO}_{4}{ }^{2-}, \mathrm{NH}_{4}{ }^{+}, \mathrm{K}^{+}, \mathrm{BC}$ in the fine fraction) and $10-20 \%$ for other species. The analytical accuracy for coarse nitrate is less than $10 \%$; however, given the possible loss of nitrate from the polycarbonate filters during sampling and sample storage, the values for coarse $\mathrm{NO}_{3}{ }^{-2}$ are likely to be underestimates of the actual values that exist in the atmosphere.

Comparison of chemical compositions of $\mathrm{PM}_{2.2}$ and $\mathrm{PM}_{2.2-10}$ from the urban and rural sites

The mean concentrations of particulate constituents at the two sites and the urban-to-rural concentration ratios (URR) are shown in Table 1 and Fig. 2, respectively. While the mean fine particles mass concentration (FM) is similar for the two sites, the mean coarse particles mass concentration $(\mathrm{CM})$ is about two times greater in Hanoi. Accordingly, few urban-rural differences were found in the concentrations of major constituents in $\mathrm{PM}_{2.2}$ such as $\mathrm{SO}_{4}{ }^{2-}, \mathrm{BC}$, and $\mathrm{K}^{+}$, while coarse mineral constituents ( $\mathrm{Si}, \mathrm{Al}, \mathrm{Fe}, \mathrm{Ti})$, as well as coarse sulfate and nitrate, are from 1.3 to 2 times more abundant in Hanoi.

The URRs are highest (2.1-4.6) for $\mathrm{Zn}, \mathrm{Pb}, \mathrm{Ca}$, and $\mathrm{Ca}^{2+}$ in both $\mathrm{PM}_{2.2}$ and $\mathrm{PM}_{2.2-10}$, reflecting the impact of traffic and construction activities in Hanoi. Leaded gasoline has only begun to be phased out since 2001 , so that some amount of traffic-related lead could still be found in the study period. Zinc comes from tire and brake abrasion, as well as from lubricating oil mixed with gasoline for twostroke motorcycles and three-wheeled vehicles. The URR is lowest for $\mathrm{NH}_{4}^{+}$in both size fractions (0.71-0.79), apparently reflecting agriculture activities (e.g., the use of fertilizers) in rural areas.

The regional or local origin of a chemical component can be recognized by using the urban-rural correlation. For $\mathrm{PM}_{2.2}$, the correlations are high for $\mathrm{K}^{+}(0.89), \mathrm{SO}_{4}{ }^{2-}$ (0.72), $\mathrm{NH}_{4}^{+}(0.71)$, and $\mathrm{BC}(0.70)$, which were found as major components of LRT aerosols in Hanoi in our previous study (Hien et al. 2004). For coarse particles, moderate to high correlations were found for $\mathrm{NO}_{3}{ }^{-}(0.53)$ and tracers of marine aerosols, i.e., $\mathrm{Na}^{+}(0.75)$ and $\mathrm{Cl} / \mathrm{Cl}^{-}$ (0.78).

As expected, the concentrations of ionic constituents $\mathrm{Ca}^{2+}$, $\mathrm{Mg}^{2+}, \mathrm{K}^{+}$, and $\mathrm{Cl}^{-}$are less than the corresponding values for $\mathrm{Ca}, \mathrm{Mg}, \mathrm{K}$, and $\mathrm{Cl}$. The proportion of a chemical element $(E)$ occurring in airborne particles as a soluble cation or anion $(I)$ can be estimated using the coefficient $a$ in the following regression relationship

$[I]=a[E]+b$

where the square brackets refer to the concentration of the species inside. The regression coefficient $a$ is rather similar for the two sites (Table 2).

The high proportion of anion $\mathrm{Cl}^{-}$in the coarse fraction $(>72 \%)$ suggests the predominance of sea salt in $\mathrm{Cl}-$ containing coarse $\mathrm{PM}_{10}$ in Hanoi and Lucnam, even 
Table 1 Mean concentrations (in $\mathrm{ng} \mathrm{m}^{-3}$ ) of coarse and fine constituents in Hanoi (urban) and Lucnam (rural)

\begin{tabular}{|c|c|c|c|c|}
\hline & \multicolumn{2}{|l|}{ Hanoi } & \multicolumn{2}{|l|}{ Lucnam } \\
\hline & Coarse & Fine & Coarse & Fine \\
\hline $\mathrm{BC}$ & & 5,321 & & 4,711 \\
\hline $\mathrm{Al}$ & 1,244 & 255 & 881 & 312 \\
\hline $\mathrm{Ca}$ & 1,955 & 330 & 734 & 150 \\
\hline $\mathrm{Ca}^{2+}$ & 1,561 & 264 & 560 & 126 \\
\hline $\mathrm{Cl}$ & 446 & 38 & 357 & 50 \\
\hline $\mathrm{Cl}-$ & 340 & 20 & 264 & 19 \\
\hline $\mathrm{Fe}$ & 792 & 175 & 439 & 121 \\
\hline $\mathrm{K}$ & 481 & 563 & 395 & 570 \\
\hline $\mathrm{K}^{+}$ & 218 & 546 & 132 & 583 \\
\hline $\mathrm{Mg}$ & 489 & 157 & 424 & 195 \\
\hline $\mathrm{Mg}^{2+}$ & 107 & 34 & 62 & 24 \\
\hline $\mathrm{Mn}$ & 25 & 21 & 13 & 15 \\
\hline $\mathrm{Na}^{+}$ & 278 & 115 & 236 & 133 \\
\hline $\mathrm{NH}_{4}^{+}$ & 146 & 1,237 & 204 & 1,556 \\
\hline $\mathrm{NO}_{3}^{-}$ & 287 & & 150 & \\
\hline $\mathrm{Pb}$ & 29 & 111 & 11 & 45 \\
\hline $\mathrm{Si}$ & 2,530 & 559 & 1,938 & 646 \\
\hline $\mathrm{SO}_{4}{ }^{2-}$ & 2,569 & 6,022 & 1,614 & 6,763 \\
\hline $\mathrm{Ti}$ & 76 & 12 & 51 & 12 \\
\hline $\mathrm{V}$ & 4 & 3 & 4 & 3 \\
\hline $\mathrm{Zn}$ & 79 & 133 & 18 & 43 \\
\hline $\mathrm{CM}(\mathrm{FM})$ & 37,763 & 31,063 & 19,071 & 32,141 \\
\hline
\end{tabular}

though these sites are about $100 \mathrm{~km}$ away from the sea. The $\left[\mathrm{Ca}^{2+}\right] /[\mathrm{Ca}]$ and $\left[\mathrm{K}^{+}\right] /[\mathrm{K}]$ ratios are much higher than those found in original rocks and soils (Park et al. 2001; Vietnam National Institute for Soil and Fertilizers 2003). The excess amounts of $\mathrm{Ca}^{2+}$ and $\mathrm{K}^{+}$neutralize secondary sulfate and nitrate, which result from reactions of acidic sulfur and nitrogen gases with mineral particles in the atmosphere (Hien et al. 2005). The yields of these secondary constituents in different particulate types can be estimated by using the receptor models presented in the next section.
Receptor modeling

\section{Methodology}

The PMF method developed by Paatero and Tapper (1994) was applied for source receptor modeling. PMF is an advanced receptor modeling technique, which has been successfully applied in many atmospheric studies in the recent years (Lee et al. 1999; Xie et al. 1999; Liu et al. 2003; Hien et al. 2004). In this work, the procedure for selecting PMF working parameters was similar to that used previously (Hien et al. 2004, 2005). The appropriate factor model was achieved by varying the number of extracted factors and working parameters in order to find an optimal, stable, and physically interpretable factor model.

Each column (F-factor) in Tables 3, 4, 5, and 6 represents the chemical composition of a source at the monitoring site. As such, the factor loading for a cation/anion should be less than that for the respective element. In fact, there are several cases when this criterion is violated, e.g., $\left[\mathrm{Ca}^{2+}\right]>[\mathrm{Ca}]$ in factor 1 of Table 3. However, this is not a matter for concern when taking into account two factor standard deviations as a factor loading error (the factor standard deviation matrices are not shown).

Each row in Tables 3, 4, 5, and 6 shows the contributions from different sources to the mean concentration of the respective species. The ratio of the sum of factor loadings in each row and the measured mean concentration in Table 1 represents the explanatory capability of the model and is given in the last columns of Tables 3, 4, 5, and 6. PMF models are able to explain more than $90 \%$ of the measured mean concentrations of most species, except $\mathrm{Pb}$ for the Hanoi site, i.e., $51 \%$ and $71 \%$ for the $\mathrm{PM}_{2.2}$ and coarse $\mathrm{PM}_{10}$, respectively.

The significant $(p<0.01)$ coarse-fine and urban-rural correlations of G-factors are shown in Tables 7 and 8. A high coarse-fine correlation would be expected for the coarse and fine factors related to the same source. Meanwhile, a significant urban-rural correlation indicates a regional source or regional atmospheric processes governing the formation and dispersion of airborne particles.
Fig. 2 URR for coarse and $\mathrm{PM}_{2.2}$ chemical components

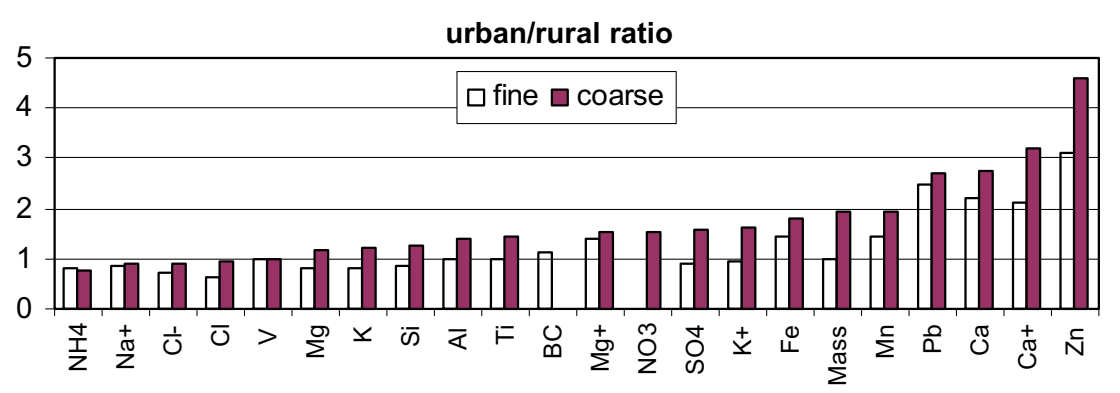


Table 2 Regression coefficient $a$ ( \pm standard error) in the relationship between ionic $(I)$ and elemental $(E)$ concentrations $[I]=a[E]+b$

\begin{tabular}{llllll}
\hline & Hanoi & & & \multicolumn{2}{l}{ Lucnam } \\
\cline { 2 - 3 } \cline { 5 - 6 } & Coarse & Fine & & Coarse & Fine \\
\hline $\mathrm{Ca}^{2+}-\mathrm{Ca}$ & $0.72 \pm 0.05$ & $0.79 \pm 0.03$ & & $0.72 \pm 0.02$ & $0.77 \pm 0.03$ \\
$\mathrm{Cl}^{-}-\mathrm{Cl}$ & $0.84 \pm 0.02$ & $0.34 \pm 0.06$ & & $0.72 \pm 0.03$ & $0.19 \pm 0.04$ \\
$\mathrm{~K}^{+}-\mathrm{K}$ & $0.49 \pm 0.04$ & $0.90 \pm 0.03$ & & $0.42 \pm 0.02$ & $0.98 \pm 0.02$ \\
$\mathrm{Mg}^{2+}-\mathrm{Mg}$ & $0.07 \pm 0.02$ & $0.07 \pm 0.02$ & & $0.07 \pm 0.02$ & $0.07 \pm 0.02$ \\
\hline
\end{tabular}

The values of $b$ are insignificant and not shown

The source apportionment was done by a multi-linear regression of coarse and fine mass loadings against Gfactors. The constant in the regression equation was set to zero. The average source contributions to the mean coarse and fine mass loadings (CM and FM) at the two sites are given in Table 9.

\section{Sources of coarse $P M_{10}$}

The assignment of coarse $\mathrm{PM}_{10}$ factors to sources was described in our previous study concerning the formation of sulfate and nitrate on coarse mineral dust particles (Hien et al. 2005). It will be briefly outlined in this section in order to facilitate the source identification of $\mathrm{PM}_{2.2}$ factors
(Tables 5 and 6 ) and the analysis of coarse-fine correlations in the next section.

The six source factors derived by PMF for Lucnam (Table 4) were also found for Hanoi with rather similar composition profiles (Tables 3). Factor 1 containing $\mathrm{Cl}$, $\mathrm{Cl}^{-}$, and $\mathrm{Na}^{+}$represents marine aerosols. Sulfate and nitrate appear in this factor, replacing chloride that is lost in the reactions of sea salt particles with acidic gases in the atmosphere. Sea breezes from the East China Sea affect the two sites, resulting in the high correlation of marine G-factors $(r=0.84$, Table 7).

The next four factors contain mineral particles with the $[\mathrm{Ca}] /[\mathrm{Si}]$ ratio or the alkalinity, decreasing from factor 2 to factor 5. Soil particles are attributed to factors 2-3, while factors 4-5 represent coal fly ash. Nitrate and sulfate appear in these factors as products of reactions of acidic gases with mineral particles in the atmosphere.

Nitrate is bound to Ca-richest soil particles in factor 2, which is called soil nitrate. Soil nitrate is four times more abundant in Hanoi than in Lucnam (Table 9), reflecting the greater abundance of both soil dust particles and nitrate precursors in Hanoi. Meanwhile, the high urban-rural correlation of soil nitrate G-factors $(r=0.62$, Table 7) indicates the role of regional atmospheric processes that govern nitrate formation reactions at the two sites. In fact, concurrent strong peaks of soil nitrate and marine aerosols were observed during February-April 2004 (Fig. 3). This
Table 3 Factor models representing source composition profiles of coarse particles in Hanoi
Factor loadings less than two factor standard deviations are left blank (unit: $\mathrm{ng} \mathrm{m}^{-3}$ )

$C A S$ coarse ammonium sulfate

\begin{tabular}{|c|c|c|c|c|c|c|c|c|}
\hline & Marine & $\begin{array}{l}\text { Soil } \\
\text { nitrate }\end{array}$ & $\begin{array}{l}\text { Soil } \\
\text { sulfate }\end{array}$ & $\begin{array}{l}\text { Distant } \\
\text { coal }\end{array}$ & $\begin{array}{l}\text { Local } \\
\text { coal }\end{array}$ & CAS & Vehicles & Explained \\
\hline $\mathrm{Al}$ & 9 & 169 & 380 & 101 & 380 & 39 & 162 & 1.00 \\
\hline $\mathrm{Ca}$ & 24 & 408 & 635 & 184 & 335 & 68 & 253 & 0.98 \\
\hline $\mathrm{Ca}^{2+}$ & 118 & 318 & 565 & 159 & 142 & 103 & 168 & 1.05 \\
\hline $\mathrm{Cl}$ & 274 & & 7 & 41 & 76 & & 15 & 0.94 \\
\hline $\mathrm{Cl}^{-}$ & 241 & & 5 & 48 & 24 & & 8 & 0.96 \\
\hline $\mathrm{Fe}$ & 10 & 160 & 287 & 68 & 129 & 27 & 95 & 0.98 \\
\hline K & & 94 & 155 & 44 & 97 & 47 & 23 & 0.96 \\
\hline $\mathrm{K}^{+}$ & 6 & 34 & 52 & 29 & 5 & 62 & 14 & 0.93 \\
\hline $\mathrm{Mg}$ & 28 & & 105 & 47 & 154 & 17 & 43 & 0.81 \\
\hline $\mathrm{Mg}^{2+}$ & 43 & & 19 & 16 & 9 & 14 & & 0.99 \\
\hline $\mathrm{Mn}$ & & 3 & 9 & & 5 & 5 & & 0.96 \\
\hline $\mathrm{Na}^{+}$ & 228 & 9 & 18 & 5 & & 28 & & 1.04 \\
\hline $\mathrm{NH}_{4}^{+}$ & & & & & & 132 & & 0.93 \\
\hline $\mathrm{NO}_{3}^{-}$ & 20 & 251 & & & & & & 0.97 \\
\hline $\mathrm{Pb}$ & & & & & 3 & 5 & 11 & 0.71 \\
\hline $\mathrm{Si}$ & 37 & 305 & 755 & 209 & 758 & 82 & 297 & 0.97 \\
\hline $\mathrm{SO}_{-}{ }^{2}$ & 180 & 303 & 771 & 63 & & 985 & 67 & 0.92 \\
\hline $\mathrm{Ti}$ & & 17 & 28 & 5 & 10 & 3 & 9 & 0.96 \\
\hline $\mathrm{V}$ & & & & & 2 & & 1 & 0.83 \\
\hline $\mathrm{Zn}$ & & 3 & 10 & 5 & 5 & 12 & 36 & 0.90 \\
\hline
\end{tabular}


Table 4 Factor models representing source composition profiles of coarse particles in Lucnam

Factor loadings less than two factor standard deviations are left blank (unit: $\mathrm{ng} \mathrm{m}^{-3}$ )

$C A S$ coarse ammonium sulfate

\begin{tabular}{|c|c|c|c|c|c|c|c|}
\hline & Marine & Soil nitrate & Soil sulfate & Distant coal & Local coal & CAS & Explained \\
\hline $\mathrm{Al}$ & 25 & & 208 & 308 & 240 & 71 & 0.98 \\
\hline $\mathrm{Ca}$ & 7 & 145 & 248 & 315 & 53 & & 1.04 \\
\hline $\mathrm{Ca}^{2+}$ & 27 & 93 & 212 & 204 & 41 & 12 & 1.05 \\
\hline $\mathrm{Cl}$ & 235 & 51 & 9 & 20 & 10 & & 0.92 \\
\hline $\mathrm{Cl}^{-}$ & 217 & 17 & & & 18 & & 0.95 \\
\hline $\mathrm{Fe}$ & 7 & 18 & 157 & 128 & 88 & 11 & 0.93 \\
\hline $\mathrm{K}$ & 6 & 39 & 114 & 155 & 48 & 37 & 1.01 \\
\hline $\mathrm{K}^{+}$ & 3 & 20 & 56 & & 20 & 38 & 1.05 \\
\hline $\mathrm{Mg}$ & 22 & & 66 & 164 & 123 & 31 & 0.97 \\
\hline $\mathrm{Mg}^{2+}$ & 18 & 12 & 16 & & 6 & 7 & 0.97 \\
\hline $\mathrm{Mn}$ & & & 6 & 4 & & 2 & 0.97 \\
\hline $\mathrm{Na}^{+}$ & 148 & 48 & 15 & & & 17 & 0.98 \\
\hline $\mathrm{NH}_{4}^{+}$ & & & & & & 195 & 0.97 \\
\hline $\mathrm{NO}_{3}^{-}$ & 5 & 123 & & & 16 & & 0.97 \\
\hline $\mathrm{Pb}$ & & & 5 & & & 2 & 0.83 \\
\hline $\mathrm{Si}$ & 64 & 46 & 444 & 740 & 414 & 170 & 0.97 \\
\hline $\mathrm{SO}_{4}{ }^{2-}$ & 17 & 165 & 349 & 122 & 24 & 791 & 0.91 \\
\hline $\mathrm{Ti}$ & 2 & & 12 & 24 & 8 & 2 & 0.93 \\
\hline V & & & & 2 & & 1 & 1.00 \\
\hline $\mathrm{Zn}$ & & & 9 & & 2 & 4 & 0.88 \\
\hline
\end{tabular}

leads to a speculation that maritime air masses from the East China Sea carry elevated amounts of nitrate precursors.

Sulfate appears in factor 2 along with nitrate, but a larger amount of sulfate is found in factor 3 (soil sulfate), the largest source of coarse $\mathrm{PM}_{10}(31 \%$ of $\mathrm{CM})$ at the two sites (Table 9).

Coal fly ash incorporates sulfate mainly in factor 4 . Because sufficient time is required for sulfate to be built up
Table 5 Factor models representing source composition profiles of fine particles in Hanoi
Factor loadings less than two factor standard deviations are left blank (unit: $\mathrm{ng} \mathrm{m}^{-3}$ )

\begin{tabular}{|c|c|c|c|c|c|c|c|c|}
\hline & LRT & Marine & $\begin{array}{l}\text { Soil } \\
\text { dust }\end{array}$ & $\begin{array}{l}\text { Distant } \\
\text { coal }\end{array}$ & $\begin{array}{l}\text { Local } \\
\text { coal }\end{array}$ & Biomassburning & Vehicles & Explained \\
\hline $\mathrm{BC}$ & 1,327 & 805 & 438 & 1,170 & 173 & 410 & 757 & 0.95 \\
\hline $\mathrm{Al}$ & & 11 & 36 & 70 & 88 & 13 & 21 & 0.94 \\
\hline $\mathrm{Ca}$ & & 43 & 159 & 90 & 20 & 12 & 17 & 1.04 \\
\hline $\mathrm{Ca}^{2+}$ & 10 & 37 & 102 & 83 & 5 & 14 & 13 & 1.00 \\
\hline $\mathrm{Cl}$ & & 4 & 7 & & 18 & 5 & 2 & 0.94 \\
\hline $\mathrm{Cl}^{-}$ & & 2 & 7 & & & 9 & & 0.97 \\
\hline $\mathrm{Fe}$ & 12 & 14 & 36 & 49 & 20 & 13 & 26 & 0.97 \\
\hline $\mathrm{K}$ & 143 & 50 & 70 & 128 & 40 & 32 & 44 & 0.90 \\
\hline $\mathrm{K}^{+}$ & 208 & 55 & 43 & 128 & 18 & 32 & 42 & 0.97 \\
\hline $\mathrm{Mg}$ & 4 & 6 & 13 & 29 & 60 & 9 & 8 & 0.83 \\
\hline $\mathrm{Mg}^{2+}$ & 4 & 9 & 3 & 11 & 2 & & & 0.92 \\
\hline $\mathrm{Mn}$ & 4 & & 2 & 5 & 3 & & 2 & 0.78 \\
\hline $\mathrm{Na}^{+}$ & 21 & 56 & 6 & 13 & 5 & 12 & & 1.00 \\
\hline $\mathrm{NH}_{4}^{+}$ & 1,009 & 83 & 34 & 11 & 11 & & 81 & 1.00 \\
\hline $\mathrm{Pb}$ & 5 & 0 & 4 & & 4 & 18 & 26 & 0.51 \\
\hline $\mathrm{Si}$ & 4 & 23 & 92 & 168 & 163 & 25 & 54 & 0.95 \\
\hline $\mathrm{SO}_{-}{ }^{2}$ & 3,851 & 566 & 321 & 387 & 156 & 132 & 518 & 0.98 \\
\hline $\mathrm{Ti}$ & & & 4 & 3 & 2 & & & 0.97 \\
\hline $\mathrm{V}$ & & 1 & & & 1 & & & 0.73 \\
\hline $\mathrm{Zn}$ & 11 & & 6 & 6 & & 24 & 81 & 0.97 \\
\hline
\end{tabular}


Table 6 Factor models representing source composition profiles of fine particles in Lucnam
Factor loadings less than two factor standard deviations are left blank (unit: $\mathrm{ng} \mathrm{m}^{-3}$ )

FAS fine ammonium sulfate

\begin{tabular}{|c|c|c|c|c|c|c|c|c|}
\hline & LRT & Marine & Soil dust & Distant coal & Local coal & Biomass & FAS & Explained \\
\hline $\mathrm{BC}$ & 1,822 & 279 & 442 & 497 & 590 & 839 & 173 & 0.99 \\
\hline $\mathrm{Al}$ & 3 & 18 & 73 & 79 & 106 & 9 & 24 & 1.00 \\
\hline $\mathrm{Ca}$ & & 22 & 20 & 43 & 18 & 41 & & 0.98 \\
\hline $\mathrm{Ca}^{2+}$ & & 22 & 11 & 33 & 5 & 50 & & 0.98 \\
\hline $\mathrm{Cl}$ & 13 & & & & 14 & 3 & 11 & 0.87 \\
\hline $\mathrm{Cl}^{-}$ & & & & & 4 & & 15 & 1.07 \\
\hline $\mathrm{Fe}$ & 10 & 11 & 37 & 19 & 28 & & & 0.92 \\
\hline $\mathrm{K}$ & 197 & 23 & 133 & 23 & 70 & 94 & 15 & 0.97 \\
\hline $\mathrm{K}^{+}$ & 239 & 26 & 121 & 20 & 50 & 95 & 23 & 0.99 \\
\hline $\mathrm{Mg}$ & 8 & 15 & 28 & 40 & 58 & 5 & 14 & 0.86 \\
\hline $\mathrm{Mg}^{2+}$ & & 10 & 7 & 3 & & & & 0.97 \\
\hline $\mathrm{Mn}$ & 4 & & 6 & & & & & 0.85 \\
\hline $\mathrm{Na}^{+}$ & 18 & 70 & 4 & 17 & & 6 & 14 & 0.99 \\
\hline $\mathrm{NH}_{4}^{+}$ & 818 & 76 & 269 & 337 & 5 & & 71 & 1.01 \\
\hline $\mathrm{Pb}$ & 18 & & 17 & & & & & 0.86 \\
\hline $\mathrm{Si}$ & 14 & 32 & 202 & 144 & 161 & 18 & 40 & 0.95 \\
\hline $\mathrm{SO}_{4}{ }^{2-}$ & 3,141 & 435 & 1,288 & 1,311 & & 239 & 234 & 0.98 \\
\hline $\mathrm{Ti}$ & & & 2 & 4 & 3 & & & 0.86 \\
\hline $\mathrm{V}$ & & & 1 & & 1 & & & 0.85 \\
\hline $\mathrm{Zn}$ & 14 & & 21 & & & 3 & & 0.94 \\
\hline
\end{tabular}

on mineral particles, factor 4 represents coal fly ash from distant coal-fired plants, while factor 5 is related to local coal burning. There are major coal-fired power and cement plants, located about 50-70 km east/northeast of Hanoi and south/southeast of Lucnam. With the southeasterly and northeasterly winds prevailing in the RRD, the impacts of these sources on the two sites are expected to be opposite. In fact, a weak, but statistically significant anticorrelation coefficient ( $r=-0.22$, Table 7 ) was found between the urban and rural G-factors 4. The impact of distant coal burning sources is slightly greater in Lucnam than in Hanoi (Table 9).

$\mathrm{NH}_{4}{ }^{+}$appears in association with $\mathrm{SO}_{4}{ }^{2-}$ in factor 6 , which is called coarse ammonium sulfate (CAS). This is the unique source of coarse ammonium and the largest source of coarse sulfate for both sites. Factor 6 contains few mineral particles, suggesting that CAS is bound to soil organic matter or coarse bioaerosols. This suggestion is also supported by the high enrichment of $\mathrm{K}$ and $\mathrm{Zn}$ in this factor.

Factor 7 appears only in the model for Hanoi and can be assigned to vehicle emissions because of the high loadings of $\mathrm{Pb}$ and $\mathrm{Zn}$. Crustal elements such as $\mathrm{Si}, \mathrm{Al}, \mathrm{Fe}$, and $\mathrm{Ca}$ are also present in its composition profile, which can be explained by the influence of road dust.

Sources of $P M_{2.2}$

Six of seven F-factors resolved by PMF have similar composition profiles for the urban and rural sites (Tables 5 and 6).

The association of $\mathrm{SO}_{4}{ }^{-2}$ with $\mathrm{NH}_{4}{ }^{+}, \mathrm{K}^{+}$, and $\mathrm{BC}$ in factor 1 can be assigned to LRT aerosol according to our previous study on sources of $\mathrm{PM}_{10}$ in different monsoon air masses arriving in Hanoi (Hien et al. 2004). With the new

Table 7 Urban-rural correlation $(p<0.01)$ of factor scores

\begin{tabular}{|c|c|c|c|c|c|c|c|c|c|}
\hline \multicolumn{5}{|l|}{ Coarse } & \multicolumn{5}{|l|}{ Fine } \\
\hline & & \multicolumn{3}{|l|}{ Lucnam } & & & \multicolumn{3}{|c|}{ Lucnam } \\
\hline & & Soil nitrate & Distant coal & Marine & & & LRT & Marine & Distant coal \\
\hline \multirow[t]{3}{*}{ Hanoi } & Soil nitrate & 0.62 & & & Hanoi & LRT & 0.77 & & \\
\hline & Distant coal & & $-0.22^{\mathrm{a}}$ & & & Marine & & 0.71 & \\
\hline & Marine & & & 0.84 & & Distant coal & & & $-0.19^{\mathrm{a}}$ \\
\hline
\end{tabular}

${ }^{\mathrm{a}} p=0.05$ 
Table 8 Coarse-fine correlation $(p<0.01)$ of factor scores

\begin{tabular}{llll}
\hline & & Hanoi & Lucnam \\
\hline Coarse & Fine & & \\
Marine & Marine & 0.91 & 0.80 \\
Soil sulfate & Soil dust & 0.54 & 0.86 \\
Distant coal & Distant coal & 0.42 & 0.77 \\
Local coal & Local coal & Insignificant & 0.39 \\
Vehicles & Vehicles & 0.57 & \\
\hline
\end{tabular}

samples and chemical composition data used in this study, the above association appears again in the PMF models for both Hanoi and Lucnam sites. The similar mass loadings at the two sites (Table 9) and the high correlation $(r=0.77)$ of G-factors (Table 7) confirm the regional homogeneity of LRT aerosol. The ammonium-to-sulfate molar ratio is also similar at the two sites, i.e., $\left[\mathrm{NH}_{4}\right] /\left[\mathrm{SO}_{4}\right]=1.4$, indicating that ammonium sulfate is the main form of sulfate in LRT aerosols. The composition profile of factor 1 indicates that sulfate and ammonium are incorporated to soot particles containing black carbon and potassium during their longrange transport in the atmosphere.

LRT is the largest source component of $\mathrm{PM}_{2.2}$ accounting for $36 \%$ of FM at the two sites. Its contributions to the 24-h fine particulate mass concentrations, however, vary with the trajectories of monsoon air masses (Draxler and Rolph 2003), ranging from less than $20 \%$ for those

Table 9 Source contributions ( \pm standard error) as percents of CM and FM

\begin{tabular}{|c|c|c|}
\hline & Hanoi & Lucnam \\
\hline \multicolumn{3}{|l|}{$\mathrm{PM}_{2.2-10}$} \\
\hline & $\mathrm{CM}=36.4 \mu \mathrm{g} \mathrm{m}^{-3}$ & $\mathrm{CM}=19.1 \mu \mathrm{g} \mathrm{m}^{-3}$ \\
\hline Soil nitrate & $20 \pm 4$ & $9 \pm 3$ \\
\hline Soil sulfate & $31 \pm 3$ & $31 \pm 3$ \\
\hline Distant coal & $8 \pm 2$ & $22 \pm 3$ \\
\hline Local coal & $8 \pm 2$ & $14 \pm 2$ \\
\hline CAS & $13 \pm 2$ & $14 \pm 2$ \\
\hline Marine & $12 \pm 3$ & $9 \pm 2$ \\
\hline Vehicles & $8 \pm 2$ & 0 \\
\hline \multicolumn{3}{|l|}{$\mathrm{PM}_{2.2}$} \\
\hline & $\mathrm{FM}=31.1 \mu \mathrm{g} \mathrm{m}^{-3}$ & $\mathrm{FM}=32.1 \mu \mathrm{g} \mathrm{m}^{-3}$ \\
\hline LRT & $36 \pm 4$ & $36 \pm 4$ \\
\hline Soil dust & $19 \pm 3$ & $9 \pm 2$ \\
\hline Distant coal & $11 \pm 2$ & $13 \pm 2$ \\
\hline Local coal & $10 \pm 3$ & $10 \pm 2$ \\
\hline Marine & $10 \pm 2$ & $6 \pm 1$ \\
\hline Biomass & $6 \pm 1$ & $22 \pm 3$ \\
\hline Vehicles & $8 \pm 2$ & 0 \\
\hline FAS & 0 & $4 \pm 1$ \\
\hline
\end{tabular}
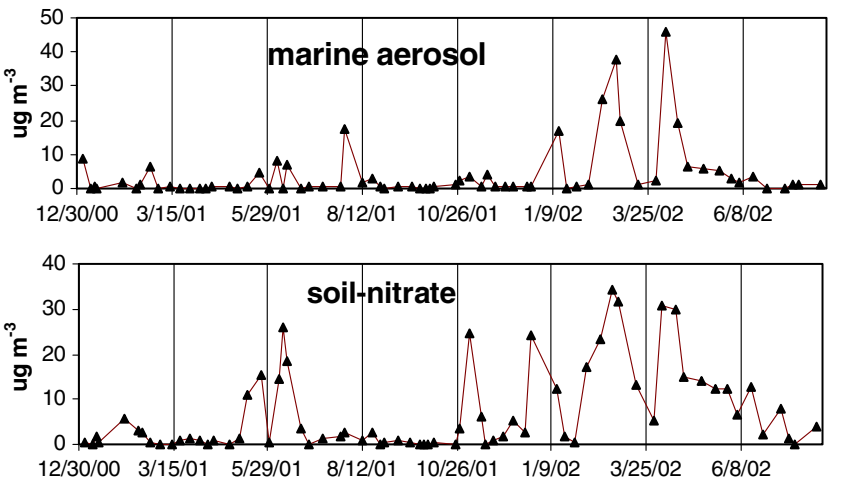

Fig. 3 Concurrent strong peaks of soil nitrate and marine aerosol Gfactors at the Hanoi site were observed during February-April 2004

traversing Thailand and Laos in summer and the South China Sea in winter to $40-60 \%$ for the cold continental air masses moving across inland China in winter (Fig. 4). Southeast China is therefore the major source area of LRT aerosol affecting the RRD.

The next four sources are similar to those of coarse $\mathrm{PM}_{10} . \mathrm{Na}^{+}$appears in factor 2, indicating marine aerosols. The high urban-rural and coarse-fine correlations of Gfactors (Tables 7 and 8) support this source assignment. Chloride is almost fully evaporated from fine sea salt particles, but the amount of sulfate in factor 2 far exceeds that which can be expected from the loss of chloride. Meanwhile, $\mathrm{SO}_{4}{ }^{2-}$ is associated with $\mathrm{NH}_{4}{ }^{+}, \mathrm{K}^{+}$, and $\mathrm{BC}$ similarly to factor 1 , indicating the mixing of marine and LRT aerosols. In fact, marine aerosols come from the Gulf of Tonkin, which is polluted by continual monsoon outflows from inland China in winter (Toan and Dac 1993; Hien et al. 2004).

As in the previous section, factors 3, 4, and 5 with decreasing $[\mathrm{Ca}] /[\mathrm{Si}]$ ratios can be assigned to soil dust, distant coal fly ash, and local coal burning, respectively. The high coarse-fine correlations of G-factors in Table 8 confirm this assignment. Fine soil dust and coarse soil sulfate come from the same source origin, as shown by the high coarse-fine correlation $(r=0.54-0.86)$.

$\mathrm{BC}, \mathrm{K}$, and $\mathrm{K}^{+}$are enriched in factor 6 , indicating biomass burning. Note the much lower $\left[\mathrm{SO}_{4}\right] /[\mathrm{K}]$ concentration ratio in biomass burning (2.5-4) than in LRT (1627) reflecting the large difference in residence time for sulfate formation on local and LRT particles (Hien et al. 2004) or the different origins of sulfate in local sources. Biomass burning is a minor source in Hanoi, but accounts for $22 \%$ of FM in Lucnam. In rural areas of northern Vietnam, farmers still use wood and rice husk as cooking fuels. Smoke is also produced by bushfires and burning of straw in the fields after harvesting.

Factor 7 is specific for each site. For Hanoi, it represents vehicle exhaust, as shown by the high loadings of $\mathrm{Pb}$ and 
Fig. 4 Five-day back trajectories (Draxler and Rolph 2003) of air masses with most abundant (red lines; $>40 \%$ of FM) and most depleted (dotted lines; $<20 \%$ of FM) LRT aerosols

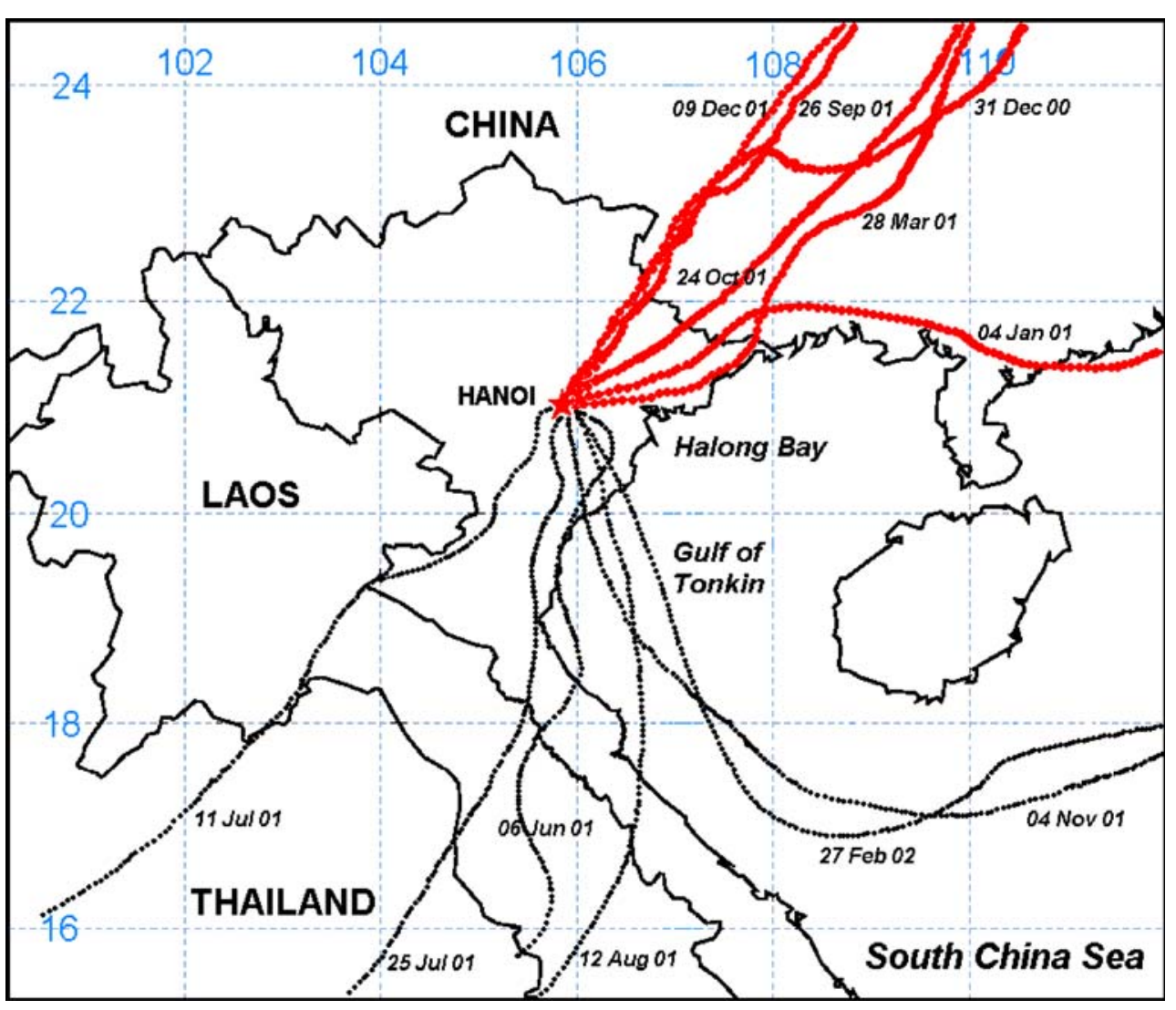

$\mathrm{Zn}$, and the significant correlation with the coarse factor 7 $(r=0.57)$. Vehicles account for $23 \%$ of the fine $\mathrm{Pb}$ mass concentration in Hanoi. $\mathrm{Pb}$ is found also in biomass burning and other factors, but in all, the PMF model is able to explain only $51 \%$ of the $\mathrm{Pb}$ fine mass concentration in Hanoi. The remaining mass could possibly be related to the various small-scale lead smelters in suburban areas. Meanwhile, the PMF model could explain $86 \%$ of $\mathrm{Pb}$ concentration in Lucnam.

The high abundance of ammonium in Lucnam leads to the emergence of factor 7 containing fine ammonium sulfate (FAS). The ammonium-to-sulfate molar ratio is 1.6, greater than that of LRT aerosols (1.4) and CAS $(\sim 1)$. Crustal matter shows up in FAS as in CAS, but no correlation was found between FAS and CAS. FAS probably represents primary aerosol and is related to the use of fertilizers in agriculture. Its contribution to FM in Lucnam, however, is insignificant (4\%).

Discussion

\section{Apportioning CM and FM to source}

The results of source apportioning (Table 9) show that at both sites, mineral dust particles consisting of soil dust (soil sulfate, soil nitrate, and CAS) followed by coal fly ash (from distant and local coal burning) dominates the
$\mathrm{PM}_{2.2-10}$ fraction. For the fine fraction, LRT is the largest source, followed by coal fly ash and biomass burning in Lucnam or soil dust in Hanoi.

The large difference in $\mathrm{CM}\left(36.4 \mathrm{\mu g} \mathrm{m}^{-3}\right.$ in Hanoi and $19.1 \mathrm{\mu g} \mathrm{m}^{-3}$ in Lucnam, Table 1) is due to the greater abundance of soil dust particles in Hanoi, i.e., 23.3 vs.

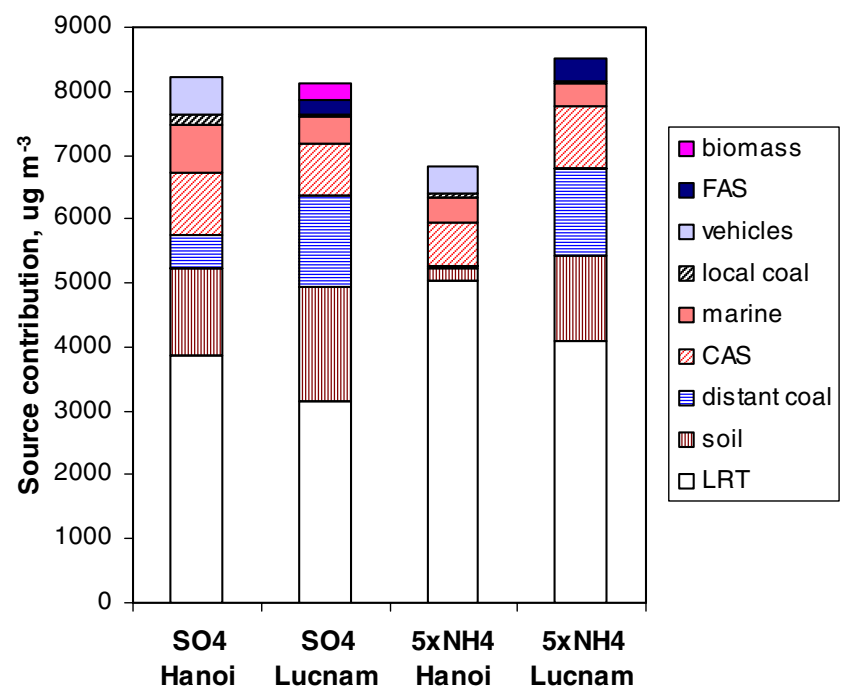

Fig. 5 Distribution of $\mathrm{SO}_{4}$ and $\mathrm{NH}_{4}$ over various particulate sources in Hanoi and Lucnam. For each particulate type, the sum of coarse and fine factor loadings is plotted. Soil includes coarse soil sulfate, coarse soil nitrate, and fine soil dust 
$10.3 \mu \mathrm{g} \mathrm{m}^{-3}$ in Lucnam, which reflects the urban-rural contrast in vehicular traffic. Soil dust in Hanoi, therefore, is mainly resuspended road dust.

The similarity of FM in Hanoi and Lucnam (31$32 \mu \mathrm{g} \mathrm{m}^{-3}$, Table 1 ) is largely due to the spatial homogeneity of LRT aerosols $\left(11.2\right.$ and $\left.11.5 \mathrm{\mu g} \mathrm{m}^{-3}\right)$ and the similar impact from coal burning $\left(6.8 \mu \mathrm{g} \mathrm{m}^{-3}\right.$ in Hanoi and $7.3 \mu \mathrm{g} \mathrm{m}^{-3}$ in Lucnam). Furthermore, while the contribution from biomass burning is larger at the rural site (7.1 vs. $\left.1.9 \mu \mathrm{g} \mathrm{m}^{-3}\right)$, fine soil dust is more abundant at the urban site (5.9 vs. $2.9 \mu \mathrm{g} \mathrm{m}^{-3}$ ). A modest contribution from vehicle exhaust in Hanoi $\left(2.5 \mathrm{\mu g} \mathrm{m}^{-3}\right)$ and FAS in Lucnam $\left(1.3 \mathrm{\mu g} \mathrm{m}^{-3}\right)$ could not produce any urban-rural gap of FM.

\section{Primary and secondary constituents: apportioning $\mathrm{SO}_{4}$ and $\mathrm{NH}_{4}$ to sources}

Four types of primary particles can be identified from the PMF F-factors, namely soot particles in LRT aerosols, mineral particles in soil/resuspended road dust and coal fly ash, soil organic matter in $\mathrm{CAS}$, and sea salt in marine aerosols. The presence of $\mathrm{SO}_{4}, \mathrm{NO}_{3}$, and $\mathrm{NH}_{4}$ in most of F-factors indicates the heterogeneous formation of secondary sulfate, nitrate, and ammonium on the surface of these primary particles (Zhang and Carmichael 1999; Zhuang et al. 1999).

Coarse nitrate is formed predominantly in Ca-richest soil dust particles as calcium nitrate (Wu and Okada 1994). Sea salt particles observed at both sites incorporate very few nitrate. Sulfate is incorporated into all types of primary particles. In coarse soil dust and coal fly ash, sulfate is neutralized by mineral alkaline materials resulting in the enrichment of $\mathrm{Ca}^{2+}$ and $\mathrm{K}^{+}$in airborne particles. In LRT soot particles, sulfate is associated with ammonium predominantly as ammonium sulfate. In CAS and the various types of $\mathrm{PM}_{2.2}$, there is a competition between mineral alkaline cations and ammonium for neutralizing sulfate.

The amount of precursor $\mathrm{SO}_{2}$ gas oxidized to coarse and fine sulfate (Table 1) is similar at the two sites $\left(6.1 \mu^{-3} \mathrm{~m}^{-3}\right.$ in Hanoi and $5.9 \mathrm{\mu g} \mathrm{m}^{-3}$ in Lucnam), suggesting the regional character of the gas-to-particle conversion processes.

The yields of sulfate and ammonium formation in different particulate types/sources estimated from the PMF F-factors models are displayed in Fig. 5. LRT soot particles incorporate $45 \%$ and $73 \%$ of $\mathrm{SO}_{4}$ and $\mathrm{NH}_{4}$ mass concentrations in Hanoi, respectively. The corresponding figures for Lucnam are $37 \%$ and $46 \%$. The long residence time of soot particles on air mass trajectories favors the accumulation of sulfate and ammonium in LRT aerosols (Ikegami et al. 2001; Zhang et al. 2001). Soil dust, coal fly ash from distant sources, and marine aerosol also provide sites for the formation of secondary sulfate and ammonium.

\section{Conclusion}

LRT aerosols, coal fly ash from major coal-fired plants, and marine aerosols are regional emissions affecting both urban and rural areas in the RRD. Large amounts of secondary sulfate, nitrate, and ammonium attached to the various airborne particles are also originated from regional precursor gases. The large impact of these regional pollutants explains the limited variability of FM across this region.

Local emissions at urban and rural sites include soil/ resuspended road dust, local coal fly ash, and biomass burning. The large urban-rural difference in CM is attributed to soil/resuspended road dust that reflects the urban-rural contrast in traffic and construction works.

The PMF models resolve four types of primary particles, namely soot particles in LRT aerosols, mineral particles in soil/road dust and coal fly ash, soil organic matter/ bioaerosol in CAS, and sea salt in marine aerosols. In the atmosphere, these primary particles provide sites for the heterogeneous conversion of precursor gases into secondary sulfate, nitrate, and ammonium. From $37 \%$ to $73 \%$, of sulfate and ammonium concentrations at the two sites are incorporated into LRT soot particles. Sulfate and nitrate are also incorporated into mineral dust particles, in which they are neutralized by mineral alkaline cations resulting in the enrichment of these cations in airborne particles as compared to the source origins.

Acknowledgment We are grateful to our colleagues of the Hanoi Institute for Nuclear Science and Technology, especially D. T. Lam and N. T. Thinh, for their helpful assistance during the implementation of this work.

Open Access This article is distributed under the terms of the Creative Commons Attribution Noncommercial License which permits any noncommercial use, distribution, and reproduction in any medium, provided the original author(s) and source are credited.

\section{References}

Clean Air Initiative for Asian Cities (2007) Motorcycle emission control on major cities. Program International Experiences and Vietnam Conditions. Workshop in Hanoi, 6 March 2007.

Draxler RR, Rolph GD (2003). HYSPLIT (HYbrid Single-Particle Lagrangian Integrated Trajectory). http:/www.arl.noaa.gov/ready/ hysplit4.html. NOAA Air Resources Laboratory, Silver Spring, MD.

Government of Vietnam/UNDP/World Bank (1995) Red River Delta Master Plan (VIE/89/034).

Hien PD, Bac VT, Tham HC, Nhan DD, Vinh LD (2002) Influence of meteorological conditions on PM2.2 and PM2.2 -10 concentrations during the monsoon season in Hanoi, Vietnam. Atmos Environ 36:3473-3484. doi:10.1016/S1352-2310(02)00295-9

Hien PD (2003) Report on National Research Project 2003-60-19/KQ, Ministry for Science and Technology (in Vietnamese).

Hien PD, Bac VT, Lam DT, Thinh NTH (2004) PMF receptor modeling of fine and coarse $\mathrm{PM}_{10}$ in air masses governing 
monsoon conditions in Hanoi, northern Vietnam. Atmos Environ 38:189-201. doi:10.1016/j.atmosenv.2003.09.064

Hien PD, Bac VT, Thinh NTH (2005) Investigation of sulphate and nitrate formation on mineral dust particles by receptor modeling. Atmos Environ 39:7231-7239

Hopke PK, Xie Y, Raunemaa T, Biegalski S, Landsberger S, Maenhaut W, Artaxo P, Cohen D (1997) Characterization of the Gent Stacked Filter Unit $\mathrm{PM}_{10}$ Sampler. Aerosol Sci Technol 27:726-735. doi:10.1080/02786829708965507

Ikegami M, Okada K, Zaizen Y, Makino Y, Jensen JB, Gras JL, Harjanto $\mathrm{H}$ (2001) Very high weight ratios of $\mathrm{S} / \mathrm{K}$ in individual haze particles over Kalimantan during the 1997 Indonesian forest fires. Atmos Environ 35:4237-4243. doi:10.1016/S1352-2310(01)00247-3

Lal YK, Tang SM (1993) A survey of air quality in Singapore. Nucl Instrum Methods B75:300-303

Lee E, Chan CK, Paatero P (1999) Application of positive matrix factorization in source apportionment of particulate pollutants in Hong Kong. Atmos Environ 33:3201-3212. doi:10.1016/S13522310(99)00113-2

Leong ST, Muttamara S, Laortanakul P (2001) Evaluation of air pollution burden from contribution of motorcycle emission in Bangkok. Water Air Soil Pollut 131:41-60. doi:10.1023/A:1011908724706

Liu W, Hopke PK, Han Y, Yi SM, Holsen TM, Cybart S, Kozlowski K, Miligan M (2003) Application of receptor modeling to atmospheric constituents at Potsdam and Stockton, N Y. Atmos Environ 37:4997-5007. doi:10.1016/j.atmosenv.2003.08.036

National Hydro-Meteorological Service of Vietnam (2004) Summary of air quality in the air monitoring network. Sci Tech HydroMeteorological J 12(528):61 in Vietnamese
Paatero P, Tapper U (1994) Positive matrix factorization: a nonnegative factor model with optimal utilization of error estimates of data values. Environmetrics 5:111-126. doi:10.1002/ env.3170050203

Park SS, Bae MS, Kim YJ (2001) Chemical composition and source apportionment of PM2.5 particles in the Sihwa area. Korea. J Air Waste Manage Assoc 51:393-405

The Government of the Hong Kong Special Administrative Region (2006). http://www.epd.gov.hk/epd/english/environmentinhk/air/data/

Toan PN, Dac PT (1993) The climate of Vietnam. Science and Technology, Hanoi (in Vietnamese)

Vietnam National Institute for Soils and Fertilizers (2003) Internal Report (in Vietnamese)

Wu PM, Okada K (1994) Nature of coarse nitrate particles in the atmosphere-A single particle approach. Atmos Environ 28:20532984. doi:10.1016/1352-2310(94)90473-1

Xie YL, Hopke PK, Paatero P, Barrie LA, Li SM (1999) Identification of source nature and seasonal variations of Artic aerosol by positive matrix factorization. J Atmos Sci 56:249-260. doi:10.1175/1520-0469(1999)056<0249:IOSNAS >2.0.CO;2

Zhang Y, Carmichael GR (1999) The role of mineral aerosol in tropospheric chemistry in East Asia-A model study. J Appl Meteorol 38:354-366

Zhang D, Iwasaka Y, Shi G (2001) Soot particles and their impacts on the mass cycle in the Tibetan atmosphere. Atmos Environ 35:5883-5894. doi:10.1016/S1352-2310(01)00391-0

Zhuang H, Chan CK, Fang M, Wexler AS (1999) Formation of nitrate and non-sea-salt sulphate on coarse particles. Atmos Environ 33:4223-4233. doi:10.1016/S1352-2310(99)00186-7 